\title{
Poesía colombiana CONTEMPORÁNEA (2000-2014)
}

COLOMBIAN CONTEMPORARY POETRY (2000-2014)

\section{Patricia Trujillo e Leonardo Gil Gómez}

Universidad Nacional de Colombia

Bogotá, Colombia

\section{Resumen}

Este artículo explora la obra de un grupo de poetas colombianos bajo una perspectiva doble: por una parte, las contradicciones que conlleva la crisis actual de la poesía (su marginación como forma artística en el contexto de una industria cultural que privilegia otras formas literarias), y por otra, las tensiones que hay entre el ánimo del canto, de descubrir que la poesía es una forma específica de conocimiento que permite vislumbrar una realidad diferente, más plena, que la realidad social, y el ánimo crítico, de emplear la poesía como una herramienta directa de crítica a la realidad social.

Palabras claves: Poesía colombiana contemporánea; poesía moderna; contrarrealidad; imaginación; vida cotidiana.

\section{Resumo}

Este artigo explora a obra de um grupo de poetas colombianos sob uma perspectiva dupla: por um lado, as contradiçóes provocadas pela crise atual da poesia (sua marginalização como forma artística no contexto de uma indústria cultural que privilegia outras formas literárias), e, por outro, as tensôes que há entre a força do canto, de descobrir que a poesia é uma forma específica de conhecimento que permite vislumbrar uma realidade diferente, ainda mais plena, que a realidade social, e a força crítica, de utilizar a poesia como uma ferramental direta de crítica à realidade social.

Palavras-chave: Poesia colombiana contemporânea; poesia moderna; contrarrealidade; imaginação; vida cotidiana.

\begin{abstract}
This article explores the work of a group of Colombian contemporary poets from a double perspective: on the one hand, it explores the contradictions that the actual crisis of poetry entails (its marginalization as an artistic form in the context of a cultural industry that privileges other literary forms) and, on the other, the double pressure this poetry is subject to, torn between the will to sing, the discovery that poetry is a specific form of knowledge that gives a glimpse of a different, more comprehensive, reality than social reality, and a critical intention, which conceives poetry as a tool for social criticism.
\end{abstract}

Keywords: Colombian contemporary poetry; modern poetry; counter-reality; imagination; everyday life. 
La poesía habita los márgenes de la cultura hoy en día. Otros objetos culturales de gratificación más inmediata ocupan el centro. En Colombia, las colecciones de poesía de las grandes editoriales cerraron a mediados de los años noventa, y esta se publica en pequeñas editoriales independientes. Sobrevive, también, gracias a lecturas públicas, festivales, concursos y programas radiales, en espacios cada vez más pequeños en proporción a la industria del entretenimiento (JIMÉNEZ, 1992: 314). Esta situación implica, para la poesía lírica, una dura crítica, pues ella tiene la aspiración utópica de hablar a todos los hombres.

La función de la poesía lírica en la sociedad contemporánea ha dejado de ser evidente. Y si su relación con el mundo se ha vuelto cuestionable, también se ha puesto en duda su derecho a existir. Plantearse la tarea de "crear orgánicamente la cultura de un país inorgánico, de darle espacio a nuestro mundo en la creación artística” (ROCA, 1990: 41) articulando lo popular, el arte culto y "un mejor beneficio de los bienes culturales" (ROCA, 1990: 41), como lo hace Juan Manuel Roca, uno de los poetas colombianos más importantes hoy en día, resulta difícil cuando la mayor parte de los bienes culturales se produce en serie y se concibe como mercancía. El poema, un objeto único, producto de un largo trabajo personal con el lenguaje y que, además, no se adapta fácilmente al predominio de la imagen visual, de la música y de las innovaciones tecnológicas, se resiste a esta producción en serie. Por ello, paga el precio de quedarse al margen.

Durante los años setenta, un grupo de poetas colombianos hizo frente a la crisis de la poesía mediante proclamas de renuncia al carácter específico, cerrado y sagrado del lenguaje poético. Estos poetas, agrupados en una antología titulada ;Ohhh! (1970), llegaron a tener gran reconocimiento en las décadas del ochenta y el noventa. Criticaron la poesía por carecer de objeto práctico, por ser melindrosa y artificiosa o, aún más, por ser un juego de sonidos vacío de todo contenido. La autoironía y el prosaísmo, las proclamas en contra del poema en el poema, fueron recursos ampliamente utilizados (JIMÉNEZ, 1992: 314). Actualmente, esta crítica a la poesía no es una nota predominante en Colombia. Los poetas actuales no cuestionan el lenguaje poético y ni intentan asimilarlo al lenguaje cotidiano o de los medios. El carácter problemático de la poesía se plantea en otros términos. En la obra de estos poetas hay una tensión entre dos polos: por una parte, el convencimiento de que el poema es una forma que permite resolver o, cuando menos, anticipar respuestas a los conflictos de la realidad en el terreno de lo imaginado. Esto lo logra porque la poesía moderna exige una negación de "la autoridad nor- 
mativa de la lengua dominante o de la tradición literaria” (HEANEY, 1996: 272). Por esta libertad del lenguaje, la poesía responde, mediante la imaginación, a los momentos en que la realidad atenta contra cualquier búsqueda de sentido. Por otra parte, existe la conciencia de que esta libertad no tiene ningún efecto en la realidad. En la obra de estos poetas hay momentos de duda acerca de la efectividad y el valor de la poesía, acerca de la justificación que pueda tener una tarea que, aunque tenga objetivos utópicos, alcanza tan poco público y de manera tan difícil.

Esta primera tensión en la poesía colombiana viene acompañada de otro choque interno: el contraste entre la exigencia de hacer una crítica de la realidad social, de denunciar y rechazar sus más funestas manifestaciones, y la revelación de una realidad silenciosa, inefable, más libre, que se trasluce en el lenguaje simbólico de la poesía. Buena parte de la obra de los poetas colombianos actuales se divide entre una crítica directa a la realidad en el poema y el convencimiento de que la poesía es una vía de acceso a una realidad superior, el descubrimiento de una verdad, el esfuerzo de expansión de la conciencia individual que destruye la barrera que separa el mundo espiritual del material y las limitaciones del tiempo. Esta última forma de entender la poesía implica elevarla al nivel de lo sagrado, intentar convertirla en mito creativo y creador. Este mito es una imagen utópica que critica, aunque no se refiera a ella, una situación social oprimida y opresora, a la cual impulsa más allá de sí misma, hacia una sociedad digna del hombre (ADORNO, 2003: 55).

\section{Mundo de la imaginación, mundo del misterio}

Desde sus primeros libros, publicados en la década del setenta, la poesía de Juan Manuel Roca ha tenido dos caras: por una parte, la denuncia de una realidad social violenta. Por otra, la proclamación de otra realidad, que se convierte en signo de rebelión y de libertad frente a la social, aunque no tenga el poder de cambiarla. Esta realidad puede ser la naturaleza, el reino de la imaginación, o la intuición de que algo perdido sobrevive.

Los libros que Roca ha publicado en los últimos diez años continúan con esta coexistencia, conflictiva pero complementaria, de dos mitades de la existencia. Por una parte, está el reino del misterio. Este puede ser fruto de la imaginación del niño que pinta un rebaño de nubes en una hoja de cuaderno, las ordeña y obtiene un pequeño riachuelo del que puede beber mientras afuera, en el salón de clase, el profesor lo llama inútilmente. O también puede existir independientemente del sujeto, ser el reino de lo natural y de lo inefable. Por eso, la poesía es una forma de traducir "El asombro de un pájaro / En cuyos ojos plateados gira la noche" (ROCA, 1994: s.p.), y puede 
"alumbrar las palabras que quedan / Luego de los silencios del naufragio" (ROCA, 1995: 57).

En los últimos libros de Roca, sin embargo, ha habido un mayor énfasis en el vacío. Los títulos ya son un indicio de esta insistencia en el despojo: Las hipótesis de Nadie (2006), Testamentos (2008), Biblia de pobres (2009), Pasaporte del apátrida (2011). Esta carencia afecta las dos mitades de la existencia. Por una parte, la realidad social es injusta porque priva al ser humano de cosas esenciales. En ella es patente que hay cosas y personas que hacen falta. En Biblia de pobres, la yuxtaposición de la pobreza contemporánea y las referencias a la Edad Media indican que la miseria se ha prolongado por mucho tiempo. Las enumeraciones lentas de los sitios a los que "se saca a pasear el hambre" (2009: 14) prolongan la sensación de vacío. En Pasaporte del apátrida, el documento de identidad con su foto velada "por el vendaje de la niebla" (2011: 14) y el carácter ilegible del nombre es una imagen de la desaparición del ser humano que no implica solo la muerte física. Los olvidos voluntarios, la capacidad humana para bloquear aquello de lo que uno no quiere enterarse, es parte del país de Catatonia, imagen del nuestro, un lugar donde el olvido es rey. Todo esto revela que "hay una tuerca suelta / después de ajustar todas las piezas / y acaso sea la que da vida a todo el engranaje" (2011: 28).

Por otra parte, el reino del misterio no es, en muchas ocasiones, un lugar pleno, utópico, sino el mundo de la imaginación que se sostiene sobre bases muy precarias. Por eso, en el prólogo de Un violín para Chagall (2004), el libro "es una suerte de fantasmario reunido en la casa de la memoria, una casa que aún enduendada aspira a no verse invadida por las telarañas del olvido" (2004: s.p). Scherezada narra mientras "un jardín esparce sus rosas de ceniza" (2008: 57). Sobre su cabeza siempre amenaza el silencio, la voz de los muertos. El poema bien puede terminar "como un barco de papel / en los deltas del vacío" (2006: 108) y los hombres "levantamos / empalizadas de sueño, / dejamos rastros de quien habita / entre dos nadas, / migas del horneado pan / que se llevan los pájaros" (2006: 69-70).

Y, no obstante, la carencia es también una posibilidad: el silencio sugiere la presencia velada de la palabra, la ausencia, la existencia del que falta. Nadie, el personaje de uno de los poemarios, es como los transeúntes que, para el ciego, son apenas fantasmas de su "reino luminoso". Existe, aunque en un plano inalcanzable. La ciudad que sobrevive en el recuerdo de los jubilados que se reúnen en el café es, en realidad, "una ciudad escondida en la ciudad" (2010: 70). Y por ambas "corre el persistente rumor / de que hay vida en otra parte" (2010: 72). La escalera de la casa, que se eleva milagrosamente en el aire incluso luego de que esta ha sido demolida, es transitada por los niños, el tío que volvió de Chile, la hermana de la madre, "vestida de lirio para su pri- 
mer baile" (2010: 42). La escalera conduce del vacío al vacío, pero entre esas dos inexistencias transita toda la vida. El vacío tiene, pues, un doble sentido: es marca de la injusticia histórica y de la precariedad del mundo de la libertad imaginativa, pero también conduce a la posibilidad de una vida plena. El poder de la poesía de evocar el mundo sagrado, contracara de la realidad, que ha sido arrojado por la puerta por la crítica sobre su falta de efectividad en la vida práctica, vuelve a entrar por la ventana, debido a la precariedad y limitación de esa vida.

La poesía de Benavides, como la de Roca, evoca una plenitud más allá de la vida concreta. Pero en la de Benavides hay una unión de lo viviente con lo no viviente, y una reconciliación de todos los contrarios. Uno de los epígrafes que escogió para encabezar sus libros describe bien su poesía: "He aquí la vida bullendo en torno de los muertos y la pareja de niños muertos penetrando en la vida" (2013: 105). En esta obra, el reino de lo natural o lo imaginario no es una contracara de la realidad mala, sino que está en comunicación con ella. Cierto pájaro ronda la casa de los que van a morir. Su canto "será lo último / que escuchemos / y así nuestro círculo / estará cumplido" (2008: 183). La luna, que alumbra el camino, convierte en dos al jinete que va solo: "un jinete va por el puente / el otro por el río // los dos se encontrarán / cuando entren en lo oscuro" (2013: 109). Benavides apela a la creencia romántica según la cual la unidad de la existencia está en el seno de la naturaleza. Las ocultas conexiones entre los elementos naturales abren vías con el reino del sueño y de la muerte. Garantizan que ni sueńo ni muerte son sucesos casuales, interrupciones de la vida que atañen sólo al individuo. En ellos, la vida se prolonga y adquiere su verdadero sentido. "Canta el gallo / y un crujir de hielos / se escucha en el río de la muerte // Arde en los camarotes / el leño del sueño / y un soplo de madrugada / hincha las velas" (2008: 235), dice uno de los poemas finales de La aldea desvelada. Aquí, muerte y sueño son elementos naturales y están conectados a otros. Cuál es el significado de esta relación, por qué el sueño es un tronco seco que se quema, o por qué al cantar del gallo se quieran los hielos del río, son todas cosas que quedan en lo oscuro. En ese misterio radica el poder de sugestión del poema.

En los dos primeros poemas citados más arriba aparecen imágenes del acervo popular: el animal que anuncia la hora final, la luna, el jinete y el camino solitario. Los poemas de Benavides recurren a menudo a estos ecos de la palabra colectiva. Imágenes tomadas de los cuentos de hadas, como las migajas de pan en el bosque, o de la tradición religiosa, como la escala de Jacob, el recorrer a formas métricas como el octosílabo, emergen como recordatorios de un lenguaje común, ya medio olvidado. Estos ecos incluyen también los de la adivinanza, una forma que, como el cuento de hadas, resuena con 
las experiencias de la niñez. Ambos tienen la potestad de lo antiguo. De ahí también que en la poesía de Benavides aparezcan una y otra vez los animales, esos personajes de los cuentos que acuden en ayuda de los protagonistas, o cuyas características, benignas o graciosas, son escrutadas en la adivinanza. "El habitante y la casa eres / el centro de la circunferencia / la intersección de los caminos del aire" (2013: 82), dice un breve poema. El título es la clave del acertijo: la araña es imagen de algo muy familiar, de la vida natural que se desenvuelve con soltura y, al mismo tiempo, está integrada a la unidad de la existencia, que incluye las esferas de la vida y de la muerte.

Benavides sostiene que la poesía y la adivinanza "encierran un secreto y se aproximan a él con pasos velados; sin embargo, la poesía guarda más, ambiciona un sentido más amplio" (2014: 5). Ese sentido se presenta, en su obra, como un momento instantáneo de revelación. Benavides continúa así con la tradición romántica y simbolista, que a él le viene de la lectura de José Lezama Lima, de acuerdo con la cual el poeta es un visionario que desciende al inframundo para rescatar una verdad arcana. Los términos en los que se da la visión no son descifrables, pero su fuerza radica, precisamente, en su sentido oculto:

\author{
Al final del sueño \\ una escalera de oro \\ baja tanteando \\ en la oscuridad del pozo \\ y apoya sus patas \\ en la orilla del agua \\ Al final del sueño \\ un pez negro \\ lanza destellos de oro (2013: 132).
}

La sugestión de lo sagrado y del saber arcano son fuertes en este poema: el camino del sueño es un descenso por una escalera de oro y el encuentro de un pez misterioso. La identificación entre el que sueña y el animal indica una fusión entre lo natural y el yo, anterior a las diferencias conceptuales.

Un segundo epígrafe marca la obra de Benavides. Es de Fernando Pessoa y encabeza el libro de 2001, Sin razón florecer: "Por sobre el alma el aleteo inútil / de lo que no fue ni puede ser y es todo" (2013: 135). La celebración del misterio de la existencia, de la verdad última, está contrapunteada por el hecho de que es probable que esa verdad nunca haya existido, sea una aspiración imposible del sujeto. En medio de la red de las analogías universales, como dice Octavio Paz, se abre el vacío, el descubrimiento de que en la obra está cifrado el universo, pero también su anulación (1987: 112-114). El amor aparece como el lugar al que uno se acerca pero al que nunca llega, el agua que no se ha de beber, o es volver a ver a la amada y saber que no hay 
segunda oportunidad, haber sido feliz sin darse cuenta: "Edén que no existió / y sin embargo ido" (2013: 149).

La búsqueda de una verdad última, arcaica o inicial, y de un sentido cifrado en las cosas prima en la poesía de Benavides. Este sondeo del misterio implica, también, una conciencia de la muerte. A veces, la muerte es la continuación de la existencia y fusión de los contrarios. Pero en otras ocasiones es una interrupción, un hecho desnudo, ajeno a la vida. Entonces se convierte en una crítica directa a la realidad histórica colombiana en sus más crudas manifestaciones: "Dónde dejé mi brazo / dónde mi cabeza / qué disparo voló mi dedo / qué plomo se llevó mi ojo / qué perro se cargó mi hueso" (2013: 119). En este poema, donde cada verso es una pregunta sin respuesta, el espacio en blanco que separa los versos implica la misma fragmentación que la del sujeto, abatido por las balas. Otros poemas recurren al relato, con giros populares, para encarar la muerte sin sentido: un personaje escucha el llamado de su madre, se levanta y camina hacia su casa. Los perros ladran a su paso: "cómo no iban a ladrar si me faltaba / la cabeza" (2013: 120). En otro poema, don Zenón Benavides detiene su mula para hablar con el yo: "Creo Fidel que esta vez me toca” (2013: 124). Y el yo anota: "podríamos reír como otras veces / ¿pero quién esconde la mano que señala?” (2013: 124). Aquí, la mano huesuda de la muerte, que indica la hora final a cada persona y que es parte de la tradición popular que viene del catolicismo, toma una nueva connotación: se convierte en la mano del asesino, la que escribe la lista de los que van a ser ejecutados. Las alusiones a los ajusticiamientos y a los desaparecidos, a los cadáveres sin identificación, tan comunes en Colombia en los últimos veinte años, vienen entretejidas con estos giros de la tradición colectiva, como puntadas que marcan una y otra vez la hora final de la existencia de muchos.

Crisis de las obras del hombre

La poesía de Romero apela a la creación de universos imaginados, donde todo es posible; recurre también al diálogo con personajes y elementos de la tradición pictórica, literaria y musical de Occidente.

Goya es el tema central de La quinta del sordo (2006). Romero recrea al hombre, su tiempo, su vida. Dicha recreación es una fantasmagoría: Goya dice haber conocido "un color que no ha sido revelado al hombre. Está oculto en la alacena de los dioses. Ellos urdieron conmigo el engaño. A cambio de verlo, se me pudrieron las manos pintándoles de blanco su imperio" (2006: 28). Las referencias a Dios son constantes. El artista convive en conflicto con él: por un lado ha recibido el don, ha conocido el color, pero ha pagado por ello un precio muy alto; por otro, Dios visita al artista en su casa y la humanidad del pintor lo espanta. 
Al desdoblarse y usar la primera persona para darle voz al pintor (o tomarla de él), el poeta cae en su propio artificio: "En este sótano el tiempo se mide horizontalmente y no de arriba hacia abajo, como el cuerpo real procede para desconocer a su cuerpo fantasma. En la próxima visita de G, saldré y lo dejaré aquí abajo espantándome. Es bueno turnarnos el uno al otro" (2006: 35); si Goya es el fantasma de sí mismo, el yo del poeta, también resulta víctima de la fantasmagoría: "Mi rostro es lámpara, mi cuerpo es noche. / Estoy en la parte inferior izquierda del cuadro. / Al ser mirado, en ese instante soy el que me mira" (2006: 31).

Obras de mampostería (2008) propone un debate entre lo visible y lo invisible, lo existente y lo inexistente, lo afirmado y lo negado; estas oposiciones no solo son solo parte del universo, sino más bien obra del hombre. Y la mampostería es la labor que da cabida a esas dualidades: el mampostero levanta un muro y establece límites entre lo visible y lo invisible que también implican un ocultamiento y que permean la palabra del poeta. No solo se trata del límite como punto de llegada, como el borde de lo conocido; tiene hendiduras para dar un vistazo a lo desconocido. Es un nuevo punto de partida, el mirador desde el cual la realidad, trastocada por la imaginación, adquiere nuevas formas: "Las piedras / los muros que tocas / no existen // a fuerza de no existir se hacen palpables // entre menos existan / más palpables son, / los cinco rencores de los cinco sentidos, / las cinco crueldades del cuerpo, / los cinco animales enjaulados / hacen verdaderos las piedras y los muros // la casa existe porque no existe // los mamposteros / también hacen de la oscuridad un acertijo: // construyen la casa que habita dentro del cuerpo" (2008: 39).

$\mathrm{Al}$ parecer, en Obras de mampostería, lo que no es real pero existe pertenece al universo de lo fantástico, la mentira que vale por ser fábula. Si la verdad anula la existencia, el artificio la recupera; allí donde la realidad aniquila, aparece la flor, que en Romero parece secreto vital, consuelo del hombre: "Tengo los brazos en alto, / el pecho me va a florecer, / la cabeza puede abrirse roja como una baya // seré el próximo / hombre ajardinado" (2008: 46). Otra oposición, que puede entenderse como el núcleo de toda obra humana: la capacidad creadora del hombre enfrentada a su capacidad destructiva. En la tercera sección del libro aparece Malaparte, una ciudad con un sino nefasto: "Su forma es la redondez, pero su poder es destruir el círculo" (2008: 53). Los últimos poemas del libro conducen lentamente a la subversión de la noción de paraíso; terminadas las obras de mampostería, el paraíso habrá sido un lugar del que alguien huyó, o una pesadilla, una versión inversa de la morada del hombre que, por supuesto, no es mejor que ella.

En Romero, la indagación sobre las obras del hombre lleva a concebir la poesía como forma de conocimiento. Ello exige una vasta capacidad ima- 
ginativa. A través de la imaginación, el autor pone en crisis la relación con lo real: a veces la ironiza; otras, la representa tan terrible como es, $u$ ofrece un paraíso (disfuncional, pero humano y por ello deseable) al cual fugarse. Este hilo conductor de sus libros da lugar a una búsqueda por que su voz sea versátil, que no se agote en la descripción de lo imaginado. Romero va del tono reflexivo al narrativo, de la descripción a la alegoría, de la imagen fantástica a la pregunta filosófica, del verso libre a la prosa poética. La pregunta por la escritura es constante. Romero descubre que aquel que nombra arremete contra lo existente; el tigre es encarcelado por la palabra que lo designa: "Luego de definida, sigilosa huye la palabra hacia la muerte, es como cerrar una puerta y huir, antes de que resucite lo nombrado y te destroce" (2008: 87). En esta reflexión dialoga con la tradición literaria. Otros autores se vuelven personajes que enriquecen o cuestionan las ideas del poeta, quien busca ellos respuestas elusivas: "abro el libro, pero el tigre ya se ha ido. Sigo sus huellas" (2008: 94).

Como es habitual en su poesía (lo que contrasta con autores como Roca), aquí lo imaginado no es de un universo libre; es más un ajuste de cuentas en el que el poeta (el mundo) puede o no salir bien librado; lo irreal puede ser tan nefasto como lo real y de allí proviene la fuerza de su expresión: "la irrealidad se apodera del mundo con sus armas / y hace sentir la dureza de su mano vengativa (...) el no hacer es castigado, no es el poema / lo que debemos fundar sino la vida" (2008: 82). El poeta conoce las limitaciones de su oficio; sabe que el poema no resuelve nada. Hay un curioso y tímido llamamiento a la acción, lo cual lleva su obra de una crítica, más bien elusiva, fundada en la imaginación como espacio de reflexión sobre el quehacer del hombre, a una crítica directa al propio quehacer del poeta, como afirmando la importancia de su rol en la sociedad.

El refugio de la vida cotidiana

La crítica a la realidad en la poesía de John Galán no se refiere, como la de Roca, Benavides o Romero, a los desastres de la guerra, sino a la opresión de la vida cotidiana y a la catástrofe ecológica. Por una parte, su obra da paso a breves momentos de iluminación o de dicha, que revelan una cualidad escondida de la existencia. Estos momentos entran en contraste con los problemas de la vida. Sus poemas podrían definirse como "notas del idilio en el exilio" pues dan cuenta de remansos de paz en medio de una realidad abrumadora.

Dos ciclos de poemas de su último libro, LI poemas para Li (2013) celebran momentos de plenitud en la playa y el valle. El espacio se consagra por la presencia de la amada: "a este templo / se entra flotando // ya quisiera una catedral / la luz absorta, la arena sin huellas // el silencio desnudo al fondo 
del mar // antes del verbo, antes del ser y sus visiones / en esta entraña clara empezó todo // sales radiante / del antiquísimo templo // el salado oleaje te unge" (2013: 9). Ella es la ola que él navega en el abrazo amoroso; ella tiene su hogar en el centro del valle, y marca el auge de venturosos días; su voz trae consigo el rumor del río. Quien la viera, "recrearía el origen del mundo / el paraíso perdido, jardín de las delicias” (2013: 29).

En ambos ciclos, hay uno o dos poemas que recuerdan que estas experiencias solo deben a las vacaciones. Los instantes dichosos no existen de forma independiente. Son la suspensión momentánea de una existencia que no es paradisíaca. El último poema del primer ciclo, cuenta que el yo anotó su nombre y el de la amada en una hoja y los lanzó al mar dentro de una botella, pero que ésta se reventó contra las rocas. "Qué testarudo", dice. "Querer envasar / este amor desbordado // y en arduo ayuno de carne y besos / mantener a flote días y meses / oronda la alegría" (2013: 17). El ciclo de poemas dedicado al valle termina con una lista de elementos que recuerdan el mundo al que se vuelve: "la alambrada, los cables desgastados / la hidroeléctrica, el nevado / el gas, el agua tibia, la tubería” (2013: 36-37). Y, en medio de los poemas dedicados al valle, hay una especie de mojón que los divide: "bosque adentro / el alambre de púa / desgarra el aire, / cuadricula / el inmenso verdor" (2013: 25). El alambre de púas divide el ciclo de poemas, como también divide una naturaleza que aparenta ser pura, pero que ya está parcelada.

En "notas de viaje", Galán retoma la metáfora de la vida como viaje de forma desencantada. A comienzos del siglo XXI, es una forma de supervivencia en medio de las ruinas, de las hogueras de plástico y las sandalias descoloridas que flotan en la playa: "toda la noche / retumba la consigna: / Sálvese quien pueda / sálvese lo que nos queda / Siglo XXI / vivir, dejar morir" (2013: 63). Asimismo, la relación amorosa puede verse como una "itinerante compañía" (2013: 46) que se sostiene sobre elementos precarios como "la esgrima del humor, la camaradería" (2013: 50). No obstante, el amor no resuelve los problemas diarios y se sospecha que no es un abrigo contra la crisis. Pasar el domingo haciendo el amor no es un resguardo contra la rutina del lunes, sino la "rutina de la ruptura de la rutina" (2013: 48).

Hay poemas que muestran directamente la cara problemática de la vida cotidiana. "Todo bajo control" es un ciclo dedicado a la vida contemporánea, en especial a los medios masivos de comunicación. En uno de los poemas, el padre está sentado en la sala, frente a dos televisores, uno que muestra el noticiero de la noche, el otro un partido de fútbol. Al alcance de la mano, los controles de los televisores y el teléfono celular. Encima del padre hay un retrato de los abuelos: en la mirada austera de los dos, se percibe un atisbo de ironía. Parecería que dicen que todo está bajo control. En el segundo poema 
del ciclo, hay una yuxtaposición entre una especie de epígrafe, que informa, con la retórica de los noticieros, sobre un carro bomba en Irak, el descuartizamiento de una familia en Apartadó y anuncia la sección deportiva; y la voz del yo descubre que él también está preso del influjo de los noticieros, que la voz del presentador le es "más familiar / que el vecino o el tendero" (2009: 34). En las pausas publicitarias, escribe el poema: "esta apacible iniquidad". El poema es una injusticia tan grande como la yuxtaposición de goles y asesinatos. "Todo bajo control, 4" retoma la imagen del televidente recluido en su habitación, a salvo de la realidad que se le muestra: es un minotauro encerrado en su laberinto, un laberinto hecho de un eterno presente, en el que se le da de comer, continuamente, vida y muerte. Ni siquiera Borges, pudo prever el infinito aleph de los botones del control remoto, ni su propia existencia "como un átomo / en el laberinto de la red" (2009: 39).

El poema que da título al libro, "Árbol talado", es la contracara oscura de la naturaleza como refugio del eterno presente de la vida cotidiana. El árbol ya no es una presencia viva, bajo cuyas ramas se puede disfrutar de un pequeño respiro. Es un tronco seco, con las ramas cortadas, pero al que se le ha negado convertirse en madera y terminar de perecer. En lugar de ello, sigue de pie, "a la deriva”, "Tan cerca y tan lejos / de la luna / los días / la muerte / la vida” (2009: 7). Esta imagen puede ser también la de nosotros, los televidentes, suspendidos en un presente continuo, separados tajantemente de la experiencia de los otros hombres.

\section{El arte: reino autónomo}

En la poesía de Pablo Montoya, el ámbito más libre que la realidad no es la naturaleza o el mundo del misterio, sino las artes. Sus dos últimos libros, Trazos (2007) y Programa de mano (2014) tratan de obras de arte y piezas musicales, o de pintores y compositores. Algunos de ellos son monólogos dramáticos. Los pintores o los modelos hablan de las dificultades de la composición, de la persecución de un ideal más allá de lo que los medios artísticos dan de sí, de sobrevivir a la existencia individual por medio del arte. Un anónimo pintor de Tebas, luego de enumerar las cosas que ha pintado y de sugerir que la suya es una labor de creación divina, añade: "No tengo nombre. Tal vez lo tuve. Y si tengo uno, ahora es impronunciable. Pero, si lo quieres oír, desciende los peldaños. Atraviesa los pasillos y las puertas. Entra en las tumbas. Enciende la antorcha. Mira las paredes" (2007: 2). A veces, la promesa de que la obra de arte como un mundo pleno se cumple: la obra es una forma de comunicación libre de las trabas del tiempo. En el poema dedicado a las pinturas de Lascaux se funden el momento en que se pintaron las imá- 
genes y el momento presente: "Entre gota y gota, el hombre. Pasos. Susurros. Signos. Un inmenso sueño poblado de toros, caballos y extensas cornamentas. Entre gota y gota, el movimiento de la mano. La mano que anhela el futuro. Y lo crea sin saberlo. Y entre gota y gota, nosotros. Ojos desmesurados. Fuego aún ardiente. Desvaído humo" (2007: 1).

En otras ocasiones, la obra no es puente de comunicación: el que escucha se esfuerza por reconstruir imaginativamente la existencia del compositor o del pintor, sin la certeza de que ese mundo haya existido. Incluso esta comunicación puede ser imposible: las pinturas de los sepulcros de Tierradentro son un misterio, expresión de unos hombres más dignos que los actuales. Quienes descienden a ver las tumbas, aunque imaginen "el vaho de una noche sosteniendo las vidas, las de ellos y las nuestras tramando lentamente el tiempo", (2007: 4) saben, al final, que hay un abismo entre ellos y ese mundo.

Otros poemas intentan ser el puente de comunicación con la obra artística o musical. Se explora entonces la cualidad intrínseca de la pintura o de la música. En el poema sobre Marin Marais se describe la música a través de sensaciones físicas. Las cuerdas se tocan como se roza, con el olfato, "el rocío en hojas ocres" (2014: 29). Se tocan como si se acariciara "la penumbra de un pasillo", "la tibieza de una piel nunca olvidada" (2014: 29). Se intuye también un secreto más allá del lenguaje, un lugar que se despoja del espacio, una realidad contradictoria y perecedera. Como dice Eduardo Chirinos en el prólogo a Programa de mano, "estos poemas ponen de relieve nuestra convicción de que la música es una forma de conocimiento, y también hacen evidente nuestra incapacidad para definirla” (2014: 12). El poema, que está hecho de palabras, intenta rozar aquello que la música y la pintura alcanzan por medios ajenos al lenguaje. Es una traducción imposible. Pero la expresión de esta imposibilidad ya implica una transformación de los medios expresivos de la poesía, quizá un ensanchamiento de sus límites.

Y, sin embargo, en medio la celebración de la pintura y la música, también se abre paso la realidad histórica. El poema dedicado a Cristo en la tumba, de Hans Holbein el Joven, está escrito en un tono casi de crónica periodística. Cuenta la noticia de la muerte de un estudiante a manos de la policía, las reacciones de sus compańeros, y el yo que va a recoger el cadáver y que encuentra en la morgue un cuerpo deformado por la tortura. La ironía final, descubre un equívoco, y relativiza los sentimientos de indignación del yo. El tono prosaico, la anécdota escueta, adquieren una contundencia muy fuerte por el contraste con los otros poemas del libro. La relación entre la realidad y el cuadro adquiere así un peso específico: en lugar de hablar de la obra, o reproducir sus efectos por medio de la palabra, el poema y la obra pictórica coexisten sin relación aparente. Su mera yuxtaposición ya es todo un comentario 
acerca de la pervivencia del arte y de su relación crítica con una vida que, dada la distancia temporal y geográfica del cuadro, parecería del todo ajena a ella.

La obra de Juan Felipe Robledo también celebra, como la de Montoya, el mundo del arte. Tres de sus cuatro antologías publicadas en los últimos doce años comienzan con "Nos debemos al alba", una defensa de la poesía. El poema contrasta el canto y el uso cotidiano de la palabra, que implica un intercambio de palabras "en el sucio mercado de los días" (2008: 23). Robledo retoma una metáfora ya clásica, según la cual la palabra cotidiana es una moneda desgastada que sólo facilita las transacciones humanas. En contraste, la palabra en la poesía adquiere un valor absoluto. Es el "rumor de una dulce lengua que dicta los versos en los cuales se traduce la canción del corazón" (2010b: 16); un "manantial domesticado" (2010b: 17) que trae una "salvación de verdad” (2010b: 17). La poesía da cuenta de una sabiduría oculta. Es "oscuridad reducida la del pájaro que canta aunque no lo oigamos, / y nos lleva un paso más allá, en medio del bosque que nuestro deseo aguardó" (2008: 61). Es la palabra que nombra "cosas que nunca han sido", el descubrimiento de una belleza de "devoradores ojos" (2010b: 43), cuya presencia "nos redime" (2010b: 43). Pero también tiene una tarea más humilde, la de hacer posible "que seguir estando aquí sea digno" (2010b: 30); la posibilidad de "decir esto que me rodea" (2010b: 14). La poesía es entonces el descubrimiento de las cosas simples y, por tanto, testigo de los pequeños momentos de dicha en la vida cotidiana.

Por esta razón, la obra de Robledo celebra tanto a aquel que disfruta de la simple existencia, como a aquel que busca incesantemente un sentido oculto, más allá del aquí y del ahora. Por una parte, sólo el "que ha renunciado a tiempo" (2010: 77) sabe que "Aquí, por debajo del azul vibrante, / por encima de los soleados guijarros, con las flores derramándose en el parque, / el día se eleva en el centro del tiempo". Para alcanzar este tipo de sabiduría no es necesario desafiar las convenciones, o deformar la propia alma para liberar sus energías ocultas. Sólo se necesita "quedarse en casa”, para que en el corazón no se apelotonen "el deseo y el tardo espanto".

No obstante, en la poesía de Robledo también se celebra la búsqueda de un tipo de existencia prerracional, que permita liberarse del "lastre del mundo". Surge entonces la figura del poeta como héroe que busca abolir la civilización. Es el que "atraviesa el llano y sigue golpeando la piedra y no quiere construirse un altar, sino que está vivo y lleno de resolución, y se escapa sin dejar a los otros, y sigue hacia delante, al galope, al trote, [...] y busca la dicha, busca la dicha en el cielo y en la tierra, junto al árbol y al estanque" (2010b: 46). Esta nostalgia por lo primitivo, lo natural, y la idea de que su búsqueda es una empresa heroica es la herencia romántica de esta poesía. 
La añoranza por lo primitivo y la noción de que la poesía abre una puerta hacia lo sagrado, también de raíz romántica, explican los rasgos formales de la poesía de Robledo. La suya es una poesía rica, de lujo verbal, llena de arcaísmos, de objetos y personajes exóticos. En ella aparecen las quimeras y los unicornios, los osos, las lucernarias, los juglares y las damas. Recurre a giros verbales arcaizantes ("describiré, antes bien, la inclinación de la rama por el peso del fruto" (2010b: 14) y al versículo o a la prosa con un dejo rítmico, formas de tono solemne, continuo. Este tono también se apoya en la aliteración y la anáfora, que traen los ecos de una fórmula mágica. Todos estos elementos dotan al verso de Robledo de un valor musical que, como lo señala Pablo Montoya, es una "forma de conocimiento sensorial" (2010b: 74), la afirmación de que la poesía no pertenece al orden del habla cotidiana sino que es un lenguaje sagrado, que abre la puerta a un saber oculto, inalcanzable por otros medios.

\section{El poema como espacio de reflexión lúdica}

Los últimos tres libros de Bustos [Sacrificiales (2004); Muerte y levitación de la ballena (2010); La pupila incesante (2013)] no dan cuenta de un proyecto que abarca toda su obra. Las preguntas que se hace el poeta van de un libro al otro. A la usanza del filósofo, vuelve una y otra vez sobre sus inquietudes y ofrece nuevas perspectivas. Tiene razones de sobra Darío Jaramillo para decir: "Desde su primer libro, el (...) tema central de la poesía de Rómulo Bustos es la trascendencia, el otro lado, su inasibilidad, sus reflejos en nuestra precaria realidad material, los significados que adquiere esa realidad en apariencia unívoca cuando se contrasta con las conjeturas que religiones, visionarios, hombres ordinarios y el propio poeta hacen de los transmundos" (2013: 30).

A pesar de la unidad temática, el propio Jaramillo señala un giro en la poesía de Bustos a partir de Sacrificiales: pasa de una poesía caracterizada por la brevedad, la contención y el tono ceremonial, a una en la que domina lo coloquial, lo explicativo o lo narrativo. Este rasgo se acentuará cada vez más al punto de que el carácter explicativo inicial, que entraba al poema a manera de incisos, pasa al primer plano. El proceso reflexivo se describe como si estuviera ocurriendo en el poema; el poeta, consciente de los mecanismos poéticos en la propia presentación de las ideas, busca encontrar un centro (acaso una verdad), ya no como quien quiere afirmarlo, sino como el que sabe que solo la indagación basta, aunque nunca logre su cometido.

En Sacrificiales la pregunta por lo trascendente es un ritual en el que la propia identidad se ofrenda para que la palabra pueda descubrir el mundo: "Digo / hay la escritura invisible: las silenciosas marcas / las cicatrices, los 
tatuajes que los otros / que lo otro va haciendo en ti // Hay la escritura visible: esa misma trama invisible / te hace dar la vuelta / y vas encontrando los poemas, los vas descifrando / como una hermosa y misteriosa cosecha que, de algún modo, // crees no merecer // y te vas encontrando / Te vas descifrando // Uno no escribe, a uno lo escriben -digo-" (2004: 248). El universo es un lenguaje escrito, y el sujeto no es un individuo aislado, sino que está inmerso en una trama de relaciones analógicas. La poesía de Bustos descubre, como la de Horacio Benavides, que todos los ámbitos del universo forman una unidad.

Aquí, la pregunta por lo trascendente no es resuelta de manera unívoca, sino que se expone mediante una aproximación a diversas mitologías. Y eso significa que Dios también puede ser la naturaleza o el mundo. La búsqueda de Bustos no está marcada por la angustia, como en César Vallejo, sino por cierta curiosidad que le permite encontrar reflejos de su pregunta en el mundo y acercarse a ellos deleitándose en el enigma: "Lleva el alma de regreso a casa aconseja el sabio tibetano / Y si el alma extravía los pasos en el camino / Y si no hay camino / Y si no hay casa / Y si no hay alma que llevar de regreso a casa" (2004: 264).

En Muerte y levitación de la ballena se hace evidente la intención lúdica de la poesía: "Me pregunto: ¿Por qué escribo poesía? / Y desde algún lugar del misterioso bosque / (de ese otro cuento que en vano estoy tratando de escribir en este poema) / responde el lobo / moviendo socrático la peluda cola: / "Para conocerte mejor" (2010:313). Esta reflexión sobre el oficio es constante en la obra de Bustos, y por constante hay que entender mutable; es decir que, con cada nuevo libro, los poemas relacionados con la poética exploran una nueva perspectiva del proceso creativo del autor. Por un lado, mediante el poema el autor reflexiona sobre el mundo; por el otro, el poema constituye una forma de pensamiento que se va transformando con el tiempo.

La pupila incesante señala una característica presente ya en sus libros anteriores: una contemplación que es todo menos pasiva. El poeta funda, mediante la palabra, el mundo que observa. Como el voyeur, cuya mirada materializa la satisfacción del deseo, al mirar el mundo, Bustos lo reinventa a su antojo. "El mundo es siempre sí y no. / Sino lúdico. Incongruencia. Humor cósmico / Por ejemplo / Ahora voy a enrollar este texto / que aún no es texto / Lo voy a enrollar sobre sí mismo / Sobre su sí / Sobre su no / Sobre su sino / Sobre su si no / Lo voy a enrollar sobre su signo / Para que tú / lo desenrolles en su espejeante / gnosi(s)" (2013: 367). Como es natural, aquel que se atreve a refundar el mundo pronto tiene que vérselas con el mayor de los problemas: la reinvención del lenguaje para nombrarlo. Bustos le habla al lector y el tú al que se dirige sugiere la posibilidad de que el autor se hable a sí mismo y además pone en juego el rol del lector en el poema: ¡es el lector 
el destinatario de estos poemas que juegan con la forma de mirar el mundo, que le ofrecen una nueva perspectiva?

Con la poesía de Bustos volvemos a ver una tensión entre la poesía como una forma de conocimiento, la celebración de las secretas conexiones del universo, y el convencimiento de que esta forma de conocimiento no llega al objeto (el centro) que busca; consciente de tales limitaciones, el poeta opta por un mundo imaginado que amplía la experiencia de lo real, aunque no tenga repercusiones sobre este.

De la expresión de la violencia al silencio de las ruinas

El primer libro de Cote, Puerto calcinado (2003), se asoma a la violencia desde la intimidad personal y familiar. La fuerza de los acontecimientos se manifiesta en los espacios interiores de la casa o los paisajes queridos de un puerto. En este sentido, más que una descripción física de lugares, se ofrece una descripción emotiva: existen para ser mirados, recorridos, recordados o para temer su olvido. Dicha descripción está atravesada por una experiencia sensorial cuya dominante es el calor, representado en la figura de lo ardiente.

En "La merienda", el primer poema del libro, encontramos todos estos elementos, sumados a las figuras del padre y la madre: "Acuérdate del suelo encendido, / de nosotros rascando el lomo de la tierra / como para desenterrar el verde prado. // El solar en donde repartían la merienda, / nuestro plato rebosante de cebollas / que para nosotros salaba mi madre, / que para nosotros pescaba mi padre" (2003: 13-15).

Aquí hay una voz que habla desde el futuro de un pasado irrecuperable, espacios familiares, la tierra, y el paisaje del puerto; la ausencia de Dios, a quien se le reclamará en repetidas ocasiones. Todos estos son elementos que dominan en el libro. Encontramos también una metamorfosis que lleva las huellas de una violencia cuyos agentes nunca son claros: el plato de cebollas, que es signo del encuentro familiar y que el padre y la madre proveen, es el escenario de aquellos que "pastaron de mis manos / en el trigal de las cebollas / para hacer de nuestro pan / el hambre de todos nuestros días"; como fruto de la ofensa, "la mala semilla alimenta el trigal de lo desaparecido". El trastocamiento de los espacios cotidianos por la fuerza de la violencia, que tiene los signos claros de la colombiana, es la forma en la que Cote critica la realidad. "Si supieras que afuera de la casa, / atado a la orilla del puerto quebrado, / hay un río quemante como las aceras. (...) // Si supieras / que el río no es de agua / y no trae barcos / ni maderos, / sólo pequeñas algas / crecidas en el pecho / de hombres dormidos" (2003: 19-20). El cuerpo, que aparece en la segunda sección del libro con mayor fuerza, tiene la huella de una vio- 
lencia, otra vez sugerida: "Yo digo / fervor de tierra / y es la rabia que cosecha el cuerpo / que lo taja / y lo hunde en la maleza de los días" (2003: 38); también aparece una desnudez que, si bien sugiere la expresión de lo erótico, está signada por el horror.

Por un procedimiento sutil, Cote abarca todo el sentido del adjetivo "calcinado". Aquello que fue quemado por el horror no vuelve a crecer y apenas puede decirse. Desde el futuro se contemplan escenas de un pasado feliz, antes de que quede solo un vacío. La absolución llega con la conciencia de que todo esto solo es obra del tiempo. Para resolver esta relación conflictiva con el tiempo, Cote apela a la memoria. La mayoría de interpelaciones al otro son exhortaciones al recuerdo, y el leitmotiv "acuérdate María" lo pone en evidencia. Recordar es necesario cuando los hombres son destructores, el tiempo es implacable y el poema resiste su poder destructivo.

Si en Puerto calcinado Cote hace una crítica directa a la realidad, en su siguiente libro adopta una actitud diferente: en La ruina que nombro (2015) indaga en los misterios del lenguaje; la reflexión le ha ganado terreno a la representación como vehículo del pensamiento poético. Lo que en el pasado fue espacio cotidiano ahora se encuentra en ruinas y expresarlo es tan difícil como imaginar las formas originales de lo conocido.

El libro da cuenta de las principales inquietudes de Cote: el paso del tiempo, la escritura como testimonio de este pasar y a la vez como forma de mirar atrás a través de forma que es necesariamente fragmentada: el lenguaje de Cote pone de manifiesto la dificultad que implica imaginar, a partir de las ruinas, la casa que fue. Aunque no se puede reconstruir la totalidad del sentido a partir de una expresión fragmentaria y en la cual se repiten imágenes como patrones, esa incomunicabilidad entre las ruinas del pasado y su testigo en el presente permite por lo menos mostrar las ausencias, qué o quiénes no están: "Quiero saber qué es la piedra / que tanto me conmueve. / Qué es en verdad / la ruina que nombro. / También escribir es derrumbarse" (2015:21).

La luz, junto con otros elementos de la naturaleza, configuran el universo simbólico de aquello que arrasa y permanece; que se va y es también aquello a lo que hay que aferrarse. Estas contradicciones develan lo efímero como condición de todo lo existente; algo que la voz poética a la vez teme y desea: "suele llover sobre los bordes raídos de la hierba, /los bordes que mordió la brisa /sólo para pasar sobre ti /aunque no sepas, aunque no aciertes a ver /que las cosas silenciosas se deslizan por el deseo de estar juntas" (2015: 28).

Llama la atención cómo de Puerto calcinado a La ruina que nombro, en Cote algunos temas prevalecen, pero la forma sugiere una transformación radical. La voz más reciente de Cote opta por una ruptura del lenguaje que expresa una ruptura del sentido de aquello que quiere decir. La violencia, 
que fue un tema tan importante en su primer libro, da paso al problema del tiempo y la distancia. Si Cote escribió un primer libro que se valía de la evocación de lo cotidiano para hacer frente a la realidad, en el segundo vemos cómo su sensibilidad se ha desplazado a una zona donde el misterio y la búsqueda de una verdad asociada al problema del tiempo han dado lugar a todo un universo simbólico.

\section{Contrarrealidad: ruptura del sentido}

En la obra de Sánchez se pasa de la búsqueda de alternativas a la realidad a una exploración del sinsentido. La construcción fragmentada del lenguaje denuncia el absurdo de la realidad circundante y se pregunta por una forma de decir todo aquello. Sus imágenes, en muchas ocasiones, se suceden unas a otras sin conexión aparente, como si lo que las juntara fuera algo que está más allá de un sentido que quiere ser transmitido.

En la obra de Sánchez la libertad con la que se manipula el lenguaje se convierte en una expresión de los aspectos más salvajes de la realidad. La falta de sentido señala una ruptura con la realidad o pone de manifiesto el absurdo presente en ella. La sensación que dejan sus imágenes en el lector es la de haberse asomado a la violencia. Son más los elementos alegóricos que los explícitos, pero en ellos los personajes y las cosas están resquebrajados. Y aunque no teme hablar de la guerra y la muerte, no estamos ante un panfleto que hace un inventario de las imágenes del dolor, sino ante una respuesta a ese llamado que proclamó Heaney a fundar una "contrarrealidad" en el poema que se oponga a la banalidad y la opresión del discurso hegemónico: "Dos cuerpos se necesitan / se dicen desde los poros. / Enredados en barrotes de humo / escriben país en las paredes de la guerra" (2006a: 43).

Al sentido de la obra de Sánchez se llega por acumulación más que por expresiones aisladas: hay objetos cortantes o que pueden herir: el cuchillo, las tijeras, un hacha, la puntilla; son imágenes de una amenaza escondida cuya mayor expresión es la guerra. Trabajan en contrapunto con imágenes de niños, que casi siempre están opuestos a la muerte: "Los niños / aprenden el sexo / en las patas del grillo mudo" (2006a: 19); "Hacen falta niños para que den parte de guerra. Las mujeres arrullan su última victoria" (2006a: 49). Por otro lado, encontramos el centro, que en ocasiones se asocia con el ombligo, el vientre, el sexo, el corazón o la maternidad. El poema "Siete de mi mayor" articula las dos imágenes: "Silencio en el ombligo. / Precisión de astillas en ausencia. / Candongas de ciudad / en niños que aprenden equilibrio / con un pájaro muerto" (2006a: 29). Hay sugerencias sutiles en todo ello. Sánchez construye unidades vitales que se oponen a amenazas latentes: si el vientre da la vida y los niños juegan con ella, hay que recordar que van 
a crecer para la guerra; entonces, la victoria del alumbramiento es necesariamente una derrota.

Esta construcción alegórica no solo habla de una afirmación individual, es la voz de una autodefinición colectiva. Parte de una sensación personal para llegar a un vínculo con los otros: "Probé el corazón de la alcachofa y me quedé con el centro de la ciudad. El acontecer es apenas un hilo conductor de la ambulancia que presta servicio permanente. Presiono el instante último de mis manos para esconder el duelo. No hace falta un lugar. Apenas soy la sombra de muchas almas, donde la ciudad padece confusos orificios" (2006a: 67). El duelo es el punto de inflexión: a partir de él no hace falta lugar y aquella que tuvo a elegir entre el corazón de la alcachofa y el centro de la ciudad, ahora es la sombra de muchas almas.

En Dios sobra, estorba el sentido alegórico que se va construyendo a través de las imágenes del libro, las interpelaciones a Dios o al otro, la representación de personajes en situaciones límite fruto de una violencia que está sugerida, proponen al lector una forma sensible de entender la realidad colombiana. Una que funda su propio lenguaje para decir la violencia.

Lo mismo ocurre con Gradaciones. El diccionario define la palabra "gradación" como una "figura retórica consistente en una sucesión de expresiones que van acentuando por grados el mismo significado". Si leyéramos este libro a la luz de esa definición, diríamos que estamos ante una expresión de la violencia que va cambiando de poema a poema, aunque no se pueda establecer con certeza el sentido de ese cambio.

Los poemas de Gradaciones repiten el mismo motivo: alguien, identificable con la voz poética, le habla a alguien como queriendo describir una situación en la que ese destinatario se encuentra: "Ves cómo en la distancia un grupo de suicidas avanza con su carga de palabras para el río. Los desesperados quisieron atravesar tu silencio sin ser vistos, pero el brillo de las sogas iluminó tus ojos quietos y hubo luz en la boca dormida y tus párpados tuvieron un ligero movimiento" (2006b: 6).

La descripción en segunda persona trae consigo imágenes de una violencia que es identificable por sus huellas. Así, además de suicidas y ahorcados, observamos personajes enterrados o insepultos, arrojados al solar donde ahora juegan niños, donde hormigas van y vienen o gallinas escarban la tierra. Los poemas describen situaciones en presente o pasado indistintamente, sin seguir un orden: descripción de una circunstancia o testimonio de ella.

Con Gradaciones, Sánchez afirma su voz como una apuesta por una expresión fragmentada que da cuenta del absurdo de la experiencia humana. La libertad del lenguaje permite expresar esa ruptura. En general, la obra de Sánchez ofrece un panorama de la violencia, vivida interiormente por el indi- 
viduo. En este sentido, Gradaciones configura una voz (acaso un conjunto de voces) que le hablan al lector con la cercanía de la segunda persona. Pone a ese "alguien" en situación y en ocasiones es un consuelo, una voz cómplice, pero ante todo, quiere dar testimonio de un dolor que muchas veces es indecible.

Experiencia individual, vida social

La poesía colombiana que se escribe hoy en día es un campo de debate acerca de la función de la poesía y su razón de ser. Responde no sólo a la relación conflictiva de la poesía moderna con la tradición, a la necesidad de romperla una y otra vez, sino también al carácter problemático de la realidad social. Casi podría decirse que cada poema es una respuesta tentativa a las preguntas acerca de la crítica que puede hacer la poesía a la realidad y la justificación de una actividad que, aunque abra caminos imaginativos frente a una existencia cerrada, no tiene ningún efecto directo o práctico sobre ella. La poesía no proclama ninguna verdad absoluta, no apela a principios o soluciones generales. Por el contrario, su razón de ser es la experiencia individual. No se trata tan solo de que la poesía moderna aspire a ser expresión de una experiencia única, privada, de un individuo, sino también de que cada poema aspira a ser singular, único. El amplio abanico de respuestas a los problemas de la relación entre la poesía y la realidad social, de la efectividad de la poesía, de la poesía como forma de conocimiento o crítica, es testigo de ello.

Con todo, sólo a partir de la absoluta inmersión en lo individual es que la poesía puede tocar el nervio de la experiencia social. Para ponerlo en palabras de Fernando Charry Lara, un importante escritor colombiano de la segunda mitad del siglo XX, "el poeta, condenado al destierro, adivina que en el punto extremo de su soledad termina su condena. Porque allí (...) donde parece que no hay nadie, surge el otro, surgen todos" (1975: 135).

\section{Referencias}

ADORNO, Theodor. "Discurso sobre poesía lírica y sociedad". In: . Notas sobre literatura. Traducción de Alfredo Brotons Muñoz. Madrid: Akal, 2003: 49-67. BENAVIDES, Horacio. De una a otra montaña. Obra reunida. Bogotá: Universidad Nacional, 2008. - La serena hierba. Medellín: Sílaba Editores, 2013. . Tapiz al revés ¿Dime quién es? Medellín: Sílaba Editores, 2014.

BUSTOS AGUIRRE, Rómulo. Sacrificiales. La pupila incesante: obra poética (19982013). Cartagena de Indias: Editorial Universitaria, 2013: 241-304.

. Muerte y levitación de la ballena. Madrid: Editorial Complutense: Servicio de Publicaciones Universidad Complutense, 2010. 
. La pupila incesante. La pupila incesante: obra poética (1998-2013). Cartagena de Indias: Editorial Universitaria, 2013: 361-412.

CHARRY LARA, Fernando. Lector de poesía. Bogotá: Instituto Colombiano de Cultura, 1975.

CHIRINOS, Eduardo. Prólogo a Programa de mano, de Pablo Montoya. Bogotá: Universidad Javeriana, 2014.

COTE BOTERO, Andrea. Puerto calcinado. Bogotá: Universidad Externado, 2003. . La ruina que nombro. Bogotá: Visor, 2015.

GALÁN, John Jairo. Árbol talado. Valencia: Pre-textos, 2010.

. LI poemas para Li. Medellín: Fondo Editorial Universidad EAFIT, 2013.

HEANEY, Seamus. "Enderezar la poesía”. In: De la emoción a las palabras. Traducción y edición de Francesc Parcerisas. Barcelona: Anagrama, 1996: 265-305.

JARAMILLO, Darío. Prólogo a La pupila incesante: obra poética (1998-2013), de Rómulo Bustos. Cartagena de Indias: Editorial Universitaria, 2013.

JIMÉNEZ, David. “La nueva poesía, desde 1970”. In: CRISTINA, M. T. (Org.) Gran enciclopedia de Colombia. Tomo 4. Literatura. Bogotá: Círculo de Lectores, 1992: 313-320.

MONTOYA, Pablo. Trazos. Medellín: Universidad de Antioquia, 2007.

. Programa de mano. Bogotá: Universidad Javeriana, 2014.

PAZ, Octavio. Los hijos del limo. Barcelona: Seix Barral, 1987.

ROBLEDO, Juan Felipe. La música de las horas. Bogotá: Ministerio de Cultura, 2002.

Calma después de la tormenta y otros poemas. Bogotá: Universidad Nacional de Colombia, 2002. Colección Viernes de Poesía.

. Dibujando un mapa en la noche. Montblanc, Tarragona: Ediciones Igitur, 2008.

. El don de la renuncia. Bogotá: Editorial Pontificia Universidad Javeriana, 2010a.

. Poemas ilustrados. Medellín: Tragaluz, 2010b.

ROCA, Juan Manuel. "La poesía en tiempos difíciles”. Gaceta, 3, 1990: 40-41.

. Cuaderno de mapas. Bogotá: Taller Arte Dos Gráfico, 1994.

- La farmacia del ángel. Bogotá: Editorial Norma, 1995.

. Un violín para Chagall. Bogotá: Ediciones Catapulta, 2004.

. Las hipótesis de Nadie. Bogotá: Universidad Nacional de Colombia, 2006.

- Testamentos. Bogotá: Norma, 2008.

. Biblia de pobres. Madrid: Visor, 2009.

. Temporada de estatuas. Madrid: Visor, 2010.

- Luis Vidales en clave de morse. Bogotá: Taller Arte Dos Gráfico, 2010.

. Pasaporte del apátrida. Valencia: Pre-Textos, 2011.

ROMERO G., Nelson. La quinta del sordo. Bogotá: Universidad Nacional de Colombia, 2006. 
- Obras de mampostería. Bogotá: Alcaldía Mayor de Bogotá, 2008.

. Apuntes para un cuaderno secreto. Doble Fondo IV. Líbano, Colombia:

Biblioteca Libanense de Cultura, 2011.

SÁNCHEZ, Mery Yolanda. Dios sobra, estorba. Bogotá: Universidad Nacional de Colombia, 2006a.

. Gradaciones. Bogotá: Universidad Nacional de Colombia, 2006b. Colección Viernes de Poesía.

Patricia Trujillo é Mestre em Línguas, Literaturas e Pensamento Europeu pela Queen Mary and Westfield College da Universidade de Londres e doutora em Teoria da Literatura e Literatura Comparada pela Universidade Autônoma de Barcelona. É professora do Departamento de Literatura da Universidade Nacional da Colômbia e editora da revista Literatura, teoría, historia, crítica, publicada pelo Departamento de Literatura da Universidade Nacional da Colômbia.

E-mail: ptrujillom@unal.edu.co.

Leonardo Gil Gómez é Mestre em Escrita Criativa pela Universidade Nacional da Colômbia e Licenciado em Humanidades e Língua Castelhana pela Universidade Distrital Francisco José de Caldas. Fundou e dirigiu a revista El ático (2005-2009). Escreve poesia, ensaio e narrativa. Textos seus figuraram em revistas e antologias da Colômbia, do Peru e do México. Atualmente é professor catedrático na Universidade Nacional da Colômbia e na Universidade Central. Faz parte do projeto editorial independente Himpar editores, ganhador da bolsa para projetos editoriais emergentes do Instituto Distrital para as Artes, 2014. E-mail: leogilg@gmail.com.

Recebido em: 15/09/2015

Aprovado em: 15/12/2015 